\title{
Sucesión y balance de poder en Canadá entre gobiernos liberales y conservadores
}

\author{
Aaraón Díaz Mendiburo*
}

Sucesión y balance de poder en Canadá entre gobiernos liberales y conservadores. Administraciones y procesos partidistas internos 1980-2011. México: CISAN, UNAM, 2014

A unos cuantos días de llevarse a cabo las elecciones en Canadá, el especialista en estudios políticos canadienses, Oliver Santín nos ofrece su libro titulado Sucesión y balance de poder en Canadá entre gobiernos liberales y conservadores. Administraciones y procesos partidistas internos 1980-2011. El trabajo, editado por la Universidad Nacional Autónoma de México (UNAM), a través del Centro de Investigaciones sobre América del Norte (CISAN), analiza minuciosamente el sistema político que ha imperado en Canadá desde los años ochenta hasta diciembre de 2011, momento cuando hace un alto en su exhaustiva investigación.

\section{EL SISTEMA POLÍtico CANADIENSE}

El autor, en sus primeras páginas, menciona los distintos elementos que han sido nodales en la conformación del sistema político, entre los que destaca el "Reporte Durham" (1839), que recomendaba a la Corona inglesa crear la provincia unida de Canadá bajo un sistema de partidos; el Acta de América del Norte Británica (British North America Act, 1867), documento que perfila a Canadá como una naciente comunidad autónoma;

\footnotetext{
* Doctor en antropología por la UnAm y documentalista. Profesor en la Facultad de Estudios Sociales de la Universidad Autónoma del Estado de Morelos, <faraondiaz@yahoo.com.mx>.
} 
El sistema político canadiense se ha caracterizado por establecer marcos

jurídicos que permiten un consenso general entre las provincias, lo que ha impulsado

la creación de partidos políticos. el Estatuto Westmister (1931), que establece que Canadá deja de ser una colonia de Gran Bretaña; el Acta Canadiense (Canada Act), que incluye el Acta Constitucional (Constitucional Act), ley suprema que le otorga autonomía e independencia jurídica a partir de 1982; y, por supuesto, en esta compleja amalgama histórica, figuran sus élites políticas y económicas que, desde la dominación de la Corona británica, se encuentran agrupadas fundamentalmente en dos partidos: el Partido Liberal y el Partido Conservador. Cabe mencionar que este último ha cambiado de nombre en varias ocasiones, pero su esencia ha sido la misma a lo largo del tiempo.

Oliver Santín menciona que Canadá adoptó, desde sus orígenes, un modelo parlamentario británico que se fundamentaba en la federación, en la cual, paulatinamente, las provincias fueron adquiriendo autonomía. En este sentido, el autor destaca el reto que dicho Estado ha enfrentado prácticamente desde sus orígenes con la población francófona, concentrada en Quebec, provincia que en dos ocasiones, mediante los referéndums de 1980 y 1995, ha buscado su independencia. Ante esta situación, la federación ha respondido con diversas iniciativas como reformas constitucionales, propuestas de acuerdos (Lago Meech, 1987 y Charlottetown, 1992), mociones en la Cámara de los Comunes y la iniciativa de Ley de Claridad (Clarity Act), que limitaba los intentos separatistas de la provincia de Quebec.

De acuerdo con el autor, el sistema político canadiense se ha caracterizado por establecer marcos jurídicos que permiten un consenso general entre las provincias, lo que ha impulsado la creación de partidos políticos. Sin embargo, en estos últimos 143 años ha predominado la fuerza de un duopolio hegemónico integrado por el Partido Conservador, quien ha obtenido el triunfo en dieciocho ocasiones y el Partido Liberal, quien lo ha hecho en veintitrés, situación que a su vez ha resultado un obstáculo para la consolidación de otras fuerzas políticas, pues este sistema no permite que otros partidos adquieran la fortaleza necesaria para ser un rival en las contiendas electorales.

Santín nos dibuja, con una maestría impecable, marcos históricos de factura fina que nos permiten comprender la conformación ideológica de ambos partidos. Las concepciones frente al federalismo, la relación económica con Estados Unidos y Gran Bretaña, la participación en los conflictos bélicos, el tipo de políticas sociales y económicas impuestas al interior, la postura ante la independencia y soberanía y la posición frente a 
la provincia de Quebec, son claves fundamentales del complejo andamiaje que nos ayuda en el proceso de entendimiento de dichos actores políticos.

\section{Procesos internos del Partido Liberal (1980-2011)}

En la misma tesitura de análisis histórico que el libro expone en su primer apartado, el segundo capítulo nos sitúa en el periodo que va de 1980 a 2011. A manera de introducción, el autor enlista los principales valores de la plataforma política del Partido Liberal de la siguiente manera:

a) Defensa y promoción de los derechos y libertades ciudadanas.

b) Garantía del sistema de cuidado de salud universal.

c) Mantenimiento de la paz internacional.

d) Salvaguarda de la bandera canadiense.

e) Promoción del multiculturalismo, del sistema bilingüe y de la unidad nacional.

f) Responsabilidad fiscal.

Santín continúa con un examen detallado de las características de

Un examen

detallado de las características de los líderes liberales arranca con Pierre-Elliot Trudeau quien, en la búsqueda de generar cohesión a nivel nacional, enarbola el multiculturalismo y el bilingüismo. genos que llevaron al primer ministro Trudeau a renunciar en 1984 a su cargo, entre los que destacan: la creación de un Plan Energético Nacional (PEN) que buscaba una reestructuración en la industria, pero que tocaba intereses transnacionales y oligárquicos, sobre todo de la provincia de Alberta; la crisis económica de inicios de los años ochenta a nivel global; el fortalecimiento de los conservadores por el triunfo de sus homólogos Margaret Thatcher y Ronald Reagan, y la disidencia al interior del Partido Liberal. 
Red Book expresa

la estrategia del

Partido Liberal:

invertir en un

programa

de estructura de

vivienda y disminuir el déficit a través de

la reducción de los programas oficiales

de gobierno; simplificar el cobro

de impuestos; mejorar la educación y los programas de empleo; apoyar a la pequeña y mediana empresa; estimular la participación de

la mujer en la economía; ampliar redes tecnológicas,

y convertir la industria militar en una industria con fines pacíficos.
El autor, en este recorrido histórico, analiza la muy breve estancia del primer ministro John Turner como un periodo de poca experiencia política, en donde los nombramientos clientelares, la falta de asertividad en debates televisivos, las desavenencias con los líderes del partido y el desconocimiento de proyectos eje de las propuestas liberales lo colocaron como una figura sin credibilidad ni alcances nacionales.

Asimismo, Santín vislumbra la primera gestión de Chrétien como un proceso en el que buscó, por un lado, la unidad de la federación y por el otro, el cumplimiento del Libro rojo. ${ }^{1}$ Para su segundo periodo, el autor destaca de Chrétien la importancia de su participación política al destinar más recursos a los programas sociales y su apoyo a los inuit al otorgarles el territorio de Nunavut. En políticas internacionales, apunta que realizó acciones que lo favorecieron ante el electorado.

Asimismo, el libro describe la llegada del primer ministro Paul Martin, el 12 de diciembre de 2003, como un proceso que soportó constantes presiones mediáticas, como consecuencia del escándalo por el desvío de recursos por parte de funcionarios de su partido al Partido Liberal Quebequense, para afianzar la unidad canadiense al momento del referéndum de 1995.

Al dimitir Paul Martin como líder del Partido Liberal, se eligió a Bill Graham para continuar al frente, quien básicamente en sus ocho meses de liderazgo tuvo que enfrentar dos situaciones críticas: por un lado, el reconocimiento de Quebec como nación y, por el otro, la presencia de la milicia canadiense en Afganistán.

Tras el discreto interinato de Graham como líder de la oposición, se da paso a un acalorado proceso de elecciones para votar por el nuevo líder del Partido Liberal, mismo que Santín, página por página, nos presenta a manera de novela de suspenso, sin por ello perder su rigor científico. En tal proceso, figuran los nombres de Michael Ignatieff, Bob Rae, Stéphane Dion, Gerard Kennedy, Ken Dryden, Scott Brison, Joe Volpe y Martha Hall Findlay. Stéphane Dion saldría victorioso con un proyecto de traba-

\footnotetext{
${ }^{1}$ Conocido en inglés como Red Book, éste es el documento que expresa la estrategia del Partido Liberal creado en 1993 y modificado en 1997. De principio, el libro titulado Creando oportunidades: el plan del Partido Liberal para Canadá planteó varios objetivos: la estrategia de invertir en un programa de estructura de vivienda y disminuir el déficit a través de la reducción de los programas oficiales de gobierno; simplificar el cobro de impuestos; mejorar la educación y los programas de empleo; apoyar a la pequeña y mediana empresa, estimular la participación de la mujer en la economía; ampliar redes tecnológicas, y convertir la industria militar en una industria con fines pacíficos. En su segunda reedición, bajo el título Garantizando nuestro futuro juntos, se incluyeron temas de equidad de género, diversidad, estabilidad económica, creación de empleos, medio ambiente, indígenas, entre otros (Santín: 2014: 91-92, 95).
} 
jo que abordaría sustancialmente tres áreas: la economía, la justicia social y la protección del medio ambiente y cuyo periodo concluirá con su renuncia en 2008, cuando dio camino a Michael Ignatieff como nuevo líder del partido.

El autor analiza críticamente la incongruente y contradictoria política de Ignatieff, pues la identifica con los valores del Partido Conservador, tanto en asuntos nacionales como internacionales, lo que le generó problemas al interior de su partido y con la opinión pública. Dicha situación se reflejó en los resultados de la elección federal de 2011 para integrar la XLI Legislatura de la Cámara Baja, cuando los conservadores alcanzaron 166, los neodemócratas ciento tres, los liberales treinta y cuatro, cuatro para el Bloque Quebequense y uno para el Partido Verde (Parliament of Canada, 2011, cit. por Santín, 2014: 169). Estos resultados representaron la peor derrota en la historia del Partido Liberal y su evidente crisis.

\section{Procesos internos del Partido Conservador (1980-2011)}

El último capítulo del libro expone analíticamente los procesos de liderazgo de cuatro entes políticos pertenecientes al ala conservadora: el Partido Conservador Progresista (1946-2003), el Partido Reformista (1987-2000), la Alianza Conservadora (2000-2003) y el Partido Conservador (desde 2003), este último resultado de la unión de las agrupaciones recién mencionadas.

Santín profundiza en las principales características de dichas fuerzas políticas centrándose en sus líderes. El análisis comprende el periodo de 1980 a 2011. Como dato importante, al igual que lo hizo con el Partido Liberal, al inicio de este capítulo enlista la plataforma doctrinaria del Partido Conservador de la siguiente manera:

a) Fortalecer la soberanía de Canadá, ocupando su lugar en el mundo.

b) Reforzar la federación y las instituciones democráticas.

c) Proveer un efectivo liderazgo económico y prosperidad para el futuro.

d) Combatir el crimen y garantizar la seguridad de los canadienses.

e) Mejorar el medio ambiente y la salud de los canadienses.

Posteriormente, el autor nos remite a la década de los ochenta, al momento de la renuncia de Joe Clark como primer ministro, pero quien con-
La incongruente y contradictoria política de Ignatieff se reflejó en los resultados de la elección federal de 2011 para integrar la XLI Legislatura de la Cámara Baja. Estos resultados representaron la peor derrota en la historia del Partido Liberal y su evidente crisis. 
Mulroney llevó a

cabo una política

que guardaba

estrecha relación

con el gobierno de

Estados Unidos;

sus acciones más

emblemáticas

fueron: la

negociación del

libre comercio

entre ambos

países, que iniciara

el $1^{\circ}$ de enero

de 1990, y su

estrecha amistad con Ronald Reagan. tinuaría como líder del Partido Conservador Progresista hasta 1983. De acuerdo con Santín, Clark, durante su gestión, se opuso radicalmente al PEN propuesto por el liberal Trudeau, debido a la excesiva injerencia de la federación en detrimento de la autonomía de las provincias involucradas.

Santín continúa con su análisis: toca el turno a Brian Mulroney, hombre carismático y promotor del biculturalismo a nivel nacional, quien asumiría el liderazgo del Partido Conservador Progresista en 1983 y ganara las elecciones para primer ministro en 1984. Según el autor, Mulroney llevó a cabo una política que guardaba estrecha relación con el gobierno de Estados Unidos; sus acciones más emblemáticas fueron: la negociación del libre comercio entre ambos países, que iniciara el $1^{\circ}$ de enero de 1990, y su estrecha amistad con Ronald Reagan. Mulroney impulsó los acuerdos de Lago Meech y de Charlottetown que buscaban fundamentalmente, por medio de reformas constitucionales, dar respuesta a las demandas de la provincia de Quebec y dotar de mayores atribuciones a los gobiernos provinciales, respectivamente. Ambos fueron rechazados por algunas de las provincias, situación que repercutiría en la imagen política de Mulroney. Durante su gestión enfrentó dos grandes conflictos: la construcción de un campo de golf que contravenía los intereses de los indígenas del valle de Oka y la masacre en la Escuela Politécnica de Montreal el 6 de diciembre de 1989, situación que llevó a debate nacional el libre manejo de armas en Canadá.

Mulroney renunció a su cargo de primer ministro en febrero de 1993 para dar paso a la elección de la primera mujer como líder del Partido Conservador Progresista y primera ministra de Canadá, Kim Campbell.

Santín apunta que la primera ministra, al tomar el cargo, implementó reformas para disminuir los gastos del gobierno federal e inició una campaña política que prometía disminuir el déficit y el desempleo mediante programas a corto plazo. Pasaron sólo cuatro meses cuando se tuvo que convocar a elecciones federales. Días antes de los comicios, Campbell hizo una declaración donde evidenciaba que la problemática del desempleo y del déficit conllevaba asuntos difíciles de resolver a corto plazo, por lo que los electores no aceptaron tales contradicciones en su postura, y dieron su voto de confianza como primer ministro al líder liberal Jean Chrétien.

El autor menciona que a raíz de la derrota de Campbell, Jean Charest asumió el interinato como jefe del Partido Conservador Progresista, y fue ratificado en abril de 1995 por una rotunda mayoría. Su política 
buscó reconstruir a su partido para posicionarlo, contender en las elecciones federales de 1998 y salir victorioso. Sus acciones se ciñeron a evitar la separación de Quebec. Los debates televisivos le favorecieron, pero en las elecciones, quien reafirmó su liderazgo, fue el Partido Liberal.

Santín menciona que el Partido Conservador Progresista, después de la salida de Jean Charest, no contaba con líderes para tomar el mando, por lo que Joe Clark regresó para encabezar el partido. Clark fue idóneo por sus antecedentes como político conservador del oeste canadiense, ya que pensaba que tendría mejor comunicación con los miembros del Partido Reformista en Alberta, Columbia Británica y Saskachetwan. Sin embargo, durante su gestión, que concluiría en 2002 con su renuncia, no logró fortalecer al partido ni concretar una unión con los conservadores del oeste, ya agrupados en la Alianza Conservadora.

Otro de los proyectos políticos que el autor analiza como parte del movimiento conservador es el Partido Reformista de Canadá, creado y dirigido por Preston Manning. Esta agrupación política surgió en 1987 en las provincias del oeste, como una opción a la falta de solidez del Partido Conservador Progresista, que tenía una visión política cristiana populista. Diez años más tarde se convertiría en el partido de oposición más fuerte, y enarbolaba los siguientes principios: ser el partido anglosajón de la derecha, del oeste, de las Provincias Centrales y de la gente.

Los logros políticos de dicho partido, la suma de los conservadores locales y una mayor unidad entre los conservadores a nivel nacional, impulsaron un nuevo proyecto denominado Alianza Reformista Conservadora Canadiense. Stockwell Day dirigió este nuevo partido. Él ganó las elecciones internas, pero en las federales del año 2000 sucumbió ante el Partido Liberal, lo que lo llevaría a presentar su renuncia un año después.

Peter Mackay, quien fuera el último dirigente del Partido Conservador Progresista, negoció con Stephen Harper, paladín en esos momentos de la Alianza Conservadora, la unión de los conservadores por medio de una nueva fuerza política, oficialmente reconocida el 20 de marzo de 2004 como Partido Conservador.

Stephen Harper, como líder del partido recién creado, fue el elegido para contender en las elecciones federales con un proyecto propagandístico enfocado en temas de salud, economía y la posible participación de Canadá en una nueva ofensiva militar a Irak. Las elecciones de junio de 2004 declararon triunfador a Paul Martin. Sin embargo, Harper volvió a contender en 2008 y resultó electo como primer ministro. 
La amplia y reciente bibliografía en inglés que el autor empleó, así como la casi nula atención en español sobre el sistema político

canadiense posicionan el libro de Santín como una obra fundamental en el estudio de la cultura política de Canadá.
Siguiendo la investigación de Santín, observo que han sido varias las maniobras que ha utilizado Harper para continuar al frente del gobierno canadiense, entre las que destacan la práctica del aforismo "Divide y vencerás", cuya metodología aplicó entre la oposición mediante memorándums de entendimiento sobre Afganistán firmados por el Bloque Quebequense y el Partido Liberal pero rechazados por el Partido Neodemócrata; la no aceptación, por parte de los neodemócratas, de los boletos obsequiados a todos los diputados del Parlamento para asistir a los Juegos Olímpicos de Vancouver. O más aún, en las elecciones de 2011, Harper, en una estrategia mediática, afirmó que la coalición entre liberales, neodemócratas y el Bloque Quebequense ponía en riesgo la economía de Canadá, ya que estos partidos no podrían ponerse de acuerdo. Esto provocó miedo entre el electorado, estrategia exitosa para el gobierno de Harper, quien resultaría vencedor.

Santín, para finalizar con este gran libro, fruto de una exhaustiva investigación, nos regala una detallada descripción y un profundo análisis de las estrategias que ha utilizado Harper, tanto a nivel nacional como internacional, para continuar en el poder.

A manera de conclusión, quiero expresar que éste es un análisis clave para entender el sistema político canadiense. La amplia y reciente bibliografía en inglés que el autor empleó para la construcción de su investigación, por un lado, evidencia la actualidad del trabajo y su amplio conocimiento sobre los estudios anglófonos especializados en el tema y, por otro lado, la casi nula bibliografía que existe en español sobre el sistema político canadiense. Esto último posiciona el libro de Santín como una obra fundamental en el estudio de la cultura política de Canadá. Su profundo nivel de análisis también nos invita a reflexionar acerca de nuestro propio sistema político, de los partidos y de sus estrategias en el proceso de lucha por el poder. 